\title{
Chromosomal Variation in Callus Lines and Regenerated Plantlets from Three Cultivars of Allium fistulosum L. $(2 n=16)$
}

\author{
Ki-Su Lee ${ }^{1}$ and Kanji Ono ${ }^{2}$ \\ ${ }^{1}$ Department of Natural Environmental Science, Graduate School, Kumamoto University, \\ Kumamoto 860-8555, Japan \\ ${ }^{2}$ Department of Biological Science, Faculty of Science, Kumamoto University, \\ Kumamoto 860-8555, Japan \\ Accepted October 29, 1999
}

\begin{abstract}
Summary Three callus lines from 3 Allium fistulosum L. cultivars (Kaori, Fresh, Wede) and their regenerated plantlets were examined to elucidate the relationship between chromosomal aberration and morphogenetic capacity. In these callus lines, 9 karyotypes that were altered numerically and/or structurally were found in addition to the normal diploid karyotype (type $\mathrm{S}$ ) identical to that of the mother plant. Structurally changed karyotypes occurred as a result of deletions and/or translocations. Of these, the occurrence of dicentric chromosomes arising through deletions and translocations between 2 al chromosomes was high. In regenerated plantlets from the callus lines, 3 structurally and/or numerically altered karyotypes were found in addition to the type S karyotype. Plantlets regenerated from callus cells were induced via shoot formation and subsequent root formation.
\end{abstract}

The original habitat of the welsh onion (Allium fistulosum L.) is known to be western China or Siberia, and it is one of the major vegetable crops cultivated in many countries because it is both cold- and heat-tolerant. Tissue culture of Allium species has mainly been done by regenerating plants from calli, protoplasts and meristemetic tissues of A. cepa (Lu et al. 1989, Fellner and Havranek 1992, Van der Valk et al. 1992, Song and Peffley 1994), A. sativum (Havranek and Novak 1973, El-Gizawy and Ford-Lloyd 1987, Nagasawa and Finer 1988) and A. tuberosum (Pandey et al. 1992, Shuto et al. 1993, Matsuda and Adachi 1996, Xue et al. 1997). Several studies have reported raising A. fistulosum productivity through culture (Shahin and Kaneko 1986, Phillips and Hubstenberger 1987, Pefflry 1992, Kim and Soh 1996). However, these reports did not mention any cytological details concerning chromosomal variations occurring during tissue culture.

In general, chromosomal aberrations such as numerical and structural changes are a common occurrence in calli and their regenerants. Furthermore, older calli are known to lose the capacity to regenerate plants because they either acquire high ploidy in the tissues or accumulate an increasing number of aneuploid cells that upset the balance of their chromosomal constitution (Evans and Reed 1981, Constantin 1981, Orton 1985). However, Ono et al. (1994) previously reported that callus cells of Scilla scilloides had a high regeneration capacity and that they showed various types of chromosomal aberration when subcultured for more than one year.

There have been several reports on chromosomal aberrations and plant regeneration in $\mathrm{A}$. fistulosum callus cells (Joachimiak et al. 1993, 1995), but they have not focused on changes in chromosome structure. In this paper we discuss the morphogenetic capacity in 3 A. fistulosum cultivars.

Materials and methods

\section{Plant material}

A. fistulosum L. cv. Wede from Korea, and cv. Fresh and cv. Kaori from Japan were used in this 
study.

\section{Tissue culture}

The seeds of 3 A. fistulosum cultivars were surface sterilized, with $70 \%$ ethanol for $5 \mathrm{~min}$ and then with a $1 \%$ sodium hypochlorite solution containing $0.1 \%$ alconox. The seeds were then rinsed three times with sterile water. Surface sterilized seeds were cultured on a $10 \mathrm{~cm}$ petri dish containing $1 \mathrm{ml}$ of a solid medium consisting of MS salts and vitamins (Murashige and Skoog 1962) diluted to one-tenth concentration with growth regulators and sugars omitted; the light condition was $2000 \mathrm{~lx}$ and the temperature was $25^{\circ} \mathrm{C}$. Seedlings were aseptically cut into pieces about $5 \mathrm{~mm}$ in length and these pieces were used as explants for callus induction. The basal medium for callus induction consisted of MS medium containing 2-3\% sucrose and $0.3 \%$ Gellan Gum (Kelco, Division of Merck and Co., Inc.). Various concentrations (0, 0.01, 0.1, 1, $10 \mathrm{mg} / \mathrm{l})$ of 2,4-dichlorophenoxyacetic acid (2,4-D), kinetin, and benzyladenine (BA) were added to the basal medium, individually or in different combinations. Induced calli were sub-cultured every 4 weeks on the same callus-induction medium. The medium for plant regeneration contained MS salts, vitamins, $0.5 \%$ sucrose and no growth regulators. This medium was also solidified with $0.3 \%$ Gellan Gum. The $\mathrm{pH}$ of all media was adjusted to 5.8 with $1 \mathrm{M} \mathrm{KOH}$ prior to autoclaving for $20 \mathrm{~min}$.

\section{Chromosome analysis}

7-day-old callus cells were used for chromosome analysis. After being transferred to a new medium, root tip chromosomes from regenerated plantlets and mother plants were also examined. They were pretreated with $0.002 \mathrm{M} 8$-oxyquinoline solution for $4 \mathrm{~h}$ at $25^{\circ} \mathrm{C}$ and fixed in $45 \%$ acetic acid at $0^{\circ} \mathrm{C}$ for $20 \mathrm{~min}$, then hydrolyzed in $1 \mathrm{~N} \mathrm{HCl}$ at $60^{\circ} \mathrm{C}$ for $20 \mathrm{~s}$. The samples were then stained and squashed in $2 \%$ aceto-orcein.

\section{Results}

\section{Callus establishment}

Approximately 2000 explants of the 3 cultivars were cultured with 48 concentration combinations of $2,4-\mathrm{D}(0,0.01,0.1,0.5,1.0,10.0 \mathrm{mg} / \mathrm{l})$, kinetin $(0,0.01,0.1,1.0,10.0 \mathrm{mg} / \mathrm{l})$ and benzyladenine (BA) $(0,0.01,0.1,1.0,10.0 \mathrm{mg} / \mathrm{l})$. Of these combinations, callus formation was observed, after about one month, only in cultures with media supplemented with 0.1 or $0.5 \mathrm{mg} / 12,4-\mathrm{D}$. Callus formation rates were $35 \%$ ( 21 callus-formed explants/60 cultured explants) in the former and $29 \%$ ( 23 callus-formed explants/ 80 cultured explants) in the latter. Callus formation was not observed in cultures with media containing concentrations exceeding $1 \mathrm{mg} / 1$ 2,4-D, and explants died after browning in cultures with $10 \mathrm{mg} / 1$ 2,4-D. No callus formation occurred in cultures with kinetin- and BAsupplemented media, irrespective of their concentrations. The calli of the 3 cultivars were compact and friable (Fig. 1A). They were subcultured onto media supplemented with $0.1 \mathrm{mg} / 12$ 2,4-D and used for the analysis of morphogenesis and chromosomal aberrations.

\section{Plant regeneration}

When calli of cv. Fresh were transferred to MS medium without growth regulators, green spots appeared on the surface of the calli after about 10 days. They subsequently developed into shoot primordia, and eventually into shoots (Fig. 1B, C). About one month after the start of culture, plantlets were regenerated from shoots after rooting (Fig. 1D). Similar morphogenetic processes were also observed in the other 2 cultivars.

Variation in chromosome numbers of callus lines with subculture

As shown in Table 1, the proportion of normal diploid cells $(2 n=16)$ ranged from $85.8 \%$ to 

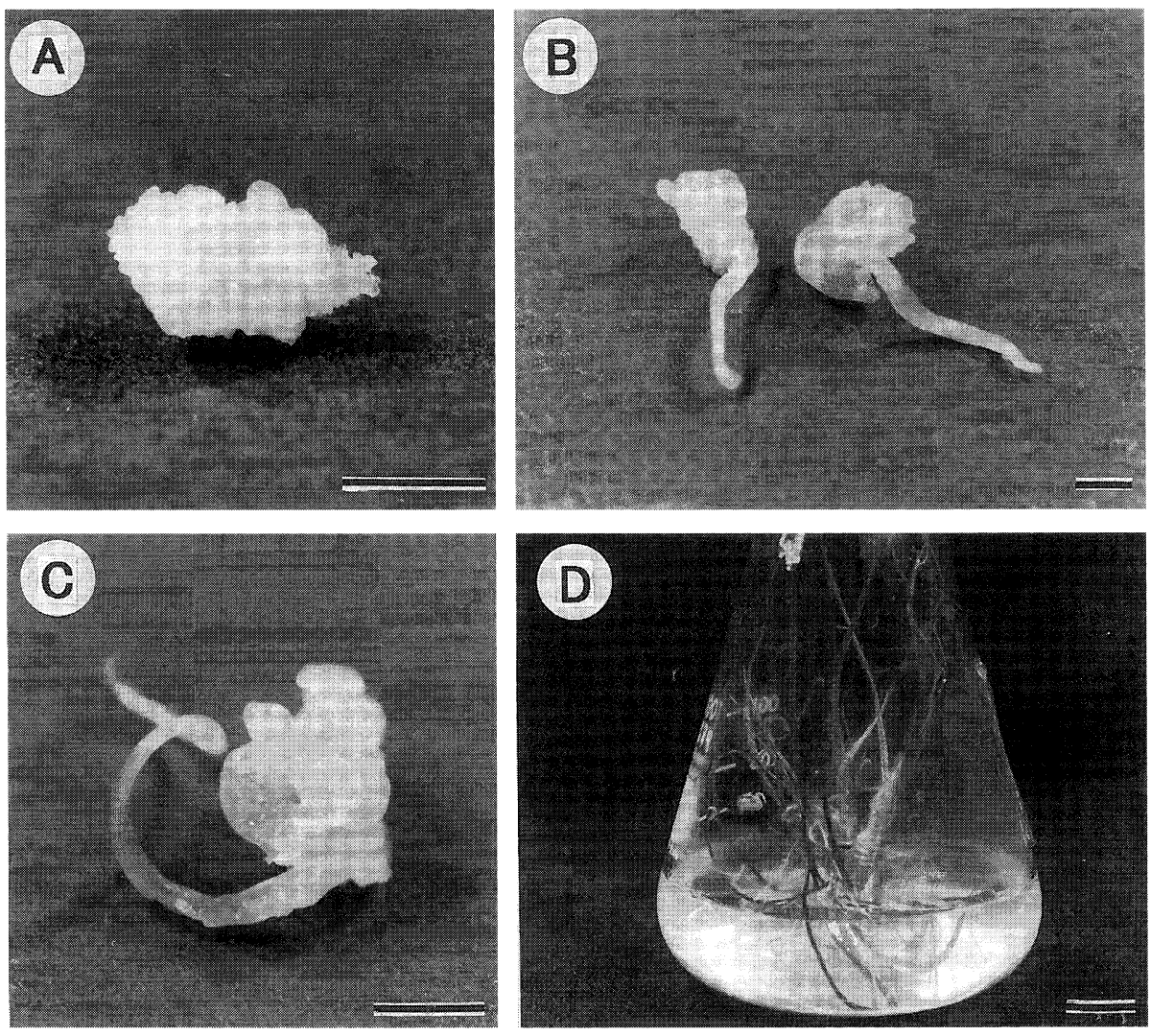

Fig. 1. The process of plantlet development in A. fistulosum cv. Fresh. A) callus. B, C) shoot development after 15 days (B) and 21 days (C) of culture. D) regenerated plantlet after 1 month of culture. Bars indicate $1 \mathrm{~cm}$ in $\mathrm{A}, \mathrm{C}, \mathrm{D}, 5 \mathrm{~mm}$ in $\mathrm{B}$.

$95.9 \%$ in 5 Kaori callus lines (K1 to K5) after 3 months. The frequency ranged from $67.2 \%$ to $81.0 \%$ after 7 months. The frequency of tetraploid cells $(2 n=32)$ was from $3.0 \%$ to $27.6 \%$ after 3 to 7 months, while other aberrant cells, including aneuploids, accounted for $0.8 \%$ to $10.6 \%$ of the cells. Various ploidy levels were observed in the callus cells during the subculture period. Kaori callus cells were mainly diploid cells in the early stages of culture, but the frequency of tetraploid cells increased as the culture period lengthened.

In the case of Fresh, the frequency of diploid cells progressively increased with the length of the culture period in lines Fresh-1 and -2, but the occurrence of tetraploid cells increased over time in the other lines (Table 2). On the other hand, the Wede callus lines showed the same tendency as the Kaori lines, with increasingly frequent tetraploid cells over time (Table 3). This was especially evident in Wede-2 and -3, where the numbers of tetraploid cells increased suddenly after 6 months of culture. The frequency of chromosome number alterations in the callus cells of the 3 cultivars therefore differed.

\section{Karyotype analysis of callus cells and regenerated plantlets}

The chromosome complements of the 3 A. fistulosum cultivars $(2 n=16)$ consisted of 8 pairs of chromosomes, a1 to a8 (Fig. 2A); each a5 pair had a satellite on the distal part of the short arm. These results agree with those of Kurita (1952). Karyotype analysis of somatic metaphase chromosomes was performed using the callus lines Kaori-1, Fresh-2 and Wede-2 that had been induced from donor plants of each cultivar. 
Table 1. The variation of chromosome numbers of calli with culture period in Allium fistulosum cv. Kaori

\begin{tabular}{|c|c|c|c|c|}
\hline \multirow{2}{*}{ Cell lines } & \multirow{2}{*}{$\begin{array}{l}\text { Culture periods after } \\
\text { callus induction } \\
\text { (months) }\end{array}$} & \multicolumn{3}{|c|}{ No. of cells of } \\
\hline & & $2 n=16(\%)$ & $2 n=32(\%)$ & others $(\%)$ \\
\hline \multirow{5}{*}{ Kaori 1} & 3 & $119(91.5)$ & $10(7.7)$ & $1(0.8)$ \\
\hline & 4 & $113(85.6)$ & $5(3.8)$ & $14(10.6)$ \\
\hline & 5 & $173(89.2)$ & $13(6.7)$ & $8(4.1)$ \\
\hline & 6 & $101(71.6)$ & $35(24.8)$ & $5(3.6)$ \\
\hline & 7 & $207(67.2)$ & $85(27.6)$ & $16(5.2)$ \\
\hline \multirow{5}{*}{ Kaori 2} & 3 & $93(95.9)$ & $4(4.1)$ & $0(0)$ \\
\hline & 4 & $97(90.6)$ & $8(7.5)$ & $2(1.9)$ \\
\hline & 5 & $105(89.7)$ & $9(7.7)$ & $3(2.6)$ \\
\hline & 6 & $125(83.3)$ & $15(10.0)$ & $10(6.7)$ \\
\hline & 7 & $132(81.0)$ & $23(14.1)$ & $8(4.9)$ \\
\hline \multirow{5}{*}{ Kaori 3} & 3 & $87(95.6)$ & $3(3.3)$ & $1(0)$ \\
\hline & 4 & $95(94.0)$ & $3(3.0)$ & $3(3.0)$ \\
\hline & 5 & $103(88.8)$ & $8(6.9)$ & $5(4.3)$ \\
\hline & 6 & $127(84.7)$ & $15(10.0)$ & $8(5.3)$ \\
\hline & 7 & $97(78.2)$ & $20(16.1)$ & $7(5.7)$ \\
\hline \multirow{5}{*}{ Kaori 4} & 3 & 85 (91.4) & $6(6.5)$ & $2(2.1)$ \\
\hline & 4 & $79(90.8)$ & $5(5.8)$ & $3(3.4)$ \\
\hline & 5 & $95(85.6)$ & $12(10.8)$ & $4(3.6)$ \\
\hline & 6 & $108(80.0)$ & $19(14.1)$ & $8(5.9)$ \\
\hline & 7 & $126(76.4)$ & $25(15.1)$ & $14(8.5)$ \\
\hline \multirow{5}{*}{ Kaori 5} & 3 & $103(85.8)$ & $14(11.7)$ & $3(2.5)$ \\
\hline & 4 & $93(85.3)$ & $12(11.0)$ & $4(3.7)$ \\
\hline & 5 & $127(78.9)$ & $23(14.3)$ & $11(6.8)$ \\
\hline & 6 & $108(78.8)$ & $21(15.3)$ & $8(5.9)$ \\
\hline & 7 & $112(73.2)$ & $28(18.3)$ & $13(8.5)$ \\
\hline
\end{tabular}

In the Kaori-1 callus line, 4 karyotypes were obvserved: type S, Type I, type I-1 and type II. Fig. 2B shows type I $(2 n=15)$ and Fig. 2 C shows type $I-1(2 n=28)$. Fig. $2 D$ shows type II $(2 n=32$, tetraploid) mitotic metaphase chromosomes. The karyotypes observed in this callus line are summarized in Table 4, and representative karyotypes are shown in Fig. 3. The type S karyotype $(2 n=16)$ was identical to that of the mother plant. The type I karyotype $(2 n=15)$ arose from type $S$ by a translocation and the elimination of a pair of al chromosomes, resulting in a dicentric chromosome. The type II karyotype was tetraploid $(2 n=32)$, which corresponds to double the type S chromosome complement. Secondary karyotype changes, resulting from alterations to previously altered karyotypes, were also found. Type I-1 $(2 \mathrm{n}=28)$ arose from type I by a doubling of the chromosome complement of type I and the elimination of two a8 chromosomes. This was followed by a structural change involving the deletion of a segment of the long arm of chromosome a8 and its translocation to the short arm of a7. The type $\mathrm{S}$ karyotype was the most frequently found, with a rate of 54.0\%; type II (tetraploid) was the second most frequent, with a rate of $20.3 \%$. Type I and type I-1 were found at the relatively low rates of $10.8 \%$ and $14.9 \%$, respectively. In the Kaori- 1 callus line, chromosomes a1, a7 and a8 were the most likely to have undergone structural changes. In regenerated plantlets from the Kaori-1 callus line, two karyotypes of type $S(2 n=16)$ and type II $(2 n=32)$ were observed (Table 4, Fig. 3), with frequencies of $77.6 \%$ and $22.4 \%$, respectively.

Four karyotypes were found in the Fresh-2 callus line: type S, type I, type II and type II-1 (Table 5, Fig. 4). Of these, type $S(2 n=16)$, type I $(2 n=15)$ and type II $(2 n=32)$ were the same as those found in the Kaori-1 callus line described above. Type II-1 $(2 n=31)$, which was a secondarily 
Table 2. The variation of chromosome numbers of calli with culture period in Allium fistulosum cv. Fresh

\begin{tabular}{|c|c|c|c|c|}
\hline \multirow{2}{*}{ Cell lines } & \multirow{2}{*}{$\begin{array}{l}\text { Culture periods after } \\
\text { callus induction } \\
\text { (months) }\end{array}$} & \multicolumn{3}{|c|}{ No. of cells of } \\
\hline & & $2 n=16(\%)$ & $2 n=32(\%)$ & others (\%) \\
\hline \multirow{5}{*}{ Fresh 1} & 3 & $150(58.6)$ & $106(41.4)$ & $0(0)$ \\
\hline & 4 & $128(59.8)$ & $86(40.2)$ & $0(0)$ \\
\hline & 5 & $97(68.3)$ & $45(31.7)$ & $0(0)$ \\
\hline & 6 & $135(72.6)$ & $47(25.3)$ & $4(2.1)$ \\
\hline & 7 & $119(90.2)$ & $11(8.3)$ & $2(1.5)$ \\
\hline \multirow{5}{*}{ Fresh 2} & 3 & $97(72.9)$ & $36(27.1)$ & $0(0)$ \\
\hline & 4 & $108(71.0)$ & $41(27.0)$ & $3(2.0)$ \\
\hline & 5 & $123(71.5)$ & $45(26.2)$ & $4(2.3)$ \\
\hline & 6 & $103(79.2)$ & $23(17.7)$ & $4(3.1)$ \\
\hline & 7 & $137(86.2)$ & $17(10.7)$ & $5(3.1)$ \\
\hline \multirow{5}{*}{ Fresh 3} & 3 & $110(94.0)$ & $7(6.0)$ & $0(0)$ \\
\hline & 4 & $105(93.8)$ & $7(6.2)$ & $0(0)$ \\
\hline & 5 & $127(93.4)$ & $9(6.6)$ & $0(0)$ \\
\hline & 6 & $94(91.3)$ & $7(6.8)$ & $2(1.9)$ \\
\hline & 7 & $118(86.1)$ & $15(11.0)$ & $4(2.9)$ \\
\hline \multirow{5}{*}{ Fresh 4} & 3 & $103(89.6)$ & $12(10.4)$ & $0(0)$ \\
\hline & 4 & $97(90.7)$ & $10(9.3)$ & $0(0)$ \\
\hline & 5 & $114(78.6)$ & $27(18.6)$ & $4(2.8)$ \\
\hline & 6 & $108(76.1)$ & $29(20.4)$ & $5(3.5)$ \\
\hline & 7 & $126(73.3)$ & $38(22.1)$ & $8(4.6)$ \\
\hline \multirow{5}{*}{ Fresh 5} & 3 & $93(87.7)$ & $13(12.3)$ & $0(0)$ \\
\hline & 4 & $126(85.1)$ & $18(12.2)$ & $4(2.7)$ \\
\hline & 5 & $114(79.7)$ & $24(16.8)$ & $5(3.5)$ \\
\hline & 6 & $123(75.5)$ & $27(16.6)$ & $13(7.9)$ \\
\hline & 7 & $134(74.0)$ & $36(19.9)$ & $11(6.1)$ \\
\hline
\end{tabular}

changed karyotype, resulted from type II by a translocation and elimination between 2 a2 chromosomes, resulting in the formation of a large chromosome. Of these karyotypes, type $\mathrm{S}$ was most frequently found with an occurrence rate of $48.0 \%$; type I was the least observed, with a rate of $10.4 \%$. The frequencies of type II and type II- 1 were $26.0 \%$ and $15.6 \%$, respectively. In this callus line, the structural chromosome changes occurred on chromosomes a1 and a2.

Three karyotypes, type $S(2 n=16)$, type II $(2 n=32)$ and type III $(2 n=18)$, were observed (Table 5, Fig. 4) in plantlets regenerated from the Fresh-2 callus line. The type III karyotype resulted from type $\mathrm{S}$ due to trisomies of chromosomes a5 (also containing a satellite) and a7. The frequencies of typeS, type II and type III were $64.1 \%, 23.1 \%$ and $12.8 \%$, respectively.

Seven karyotypes (type S, II, IV, V, VI, I-2, II-2) were observed (Table 6, Fig. 5) in the Wede-2 callus line. Of these, type IV $(2 n=15)$ and type VI $(2 n=15)$ arose from type S by the elimination of a chromosome: a1 in type IV and chromosome a2 in type V. Type VI $(2 n=17)$ arose from type S by a chromosome a 2 trisomy and the deletion of a part of both arms of chromosome a8. Type I-2 and type II-2 were secondarily changed karyotypes. Type I- 2 arose from type I by the translocation and elimination of a pair of al chromosomes and the deletion of part of a short arm of chromosome a8. Type II-2 arose from type II by a translocation and elimination between two a1 chromosomes. Of these 7 karyotypes, type $\mathrm{S}$ was the most frequently observed, as a rate of $36.2 \%$, and type VI was the least observed, at a rate of $2.3 \%$.

Despite various karyotypes being found in the Wede-2 callus line (Table 6, Fig. 5), regenerated Wede-2 plantlets consisted only of type S and type II-3. Type II-3 was derived from type II by a 
Table 3. The variation of chromosome numbers of calli with culture period in Allium fistulosum cv. Wede

\begin{tabular}{|c|c|c|c|c|}
\hline \multirow{2}{*}{ Cell lines } & \multirow{2}{*}{$\begin{array}{l}\text { Culture periods after } \\
\text { callus induction } \\
\text { (months) }\end{array}$} & \multicolumn{3}{|c|}{ No. of cells of } \\
\hline & & $2 n=16(\%)$ & $2 n=32(\%)$ & others $(\%)$ \\
\hline \multirow{5}{*}{ Wede 1} & 3 & $87(97.8)$ & $2(2.2)$ & $0(0)$ \\
\hline & 4 & $95(96.9)$ & $3(3.1)$ & $0(0)$ \\
\hline & 5 & $97(96.0)$ & $4(4.0)$ & $0(0)$ \\
\hline & 6 & $134(94.4)$ & $6(4.2)$ & $2(1.4)$ \\
\hline & 7 & $142(92.2)$ & $12(7.8)$ & $0(0)$ \\
\hline \multirow{5}{*}{ Wede 2} & 3 & $45(91.8)$ & $4(8.2)$ & $0(0)$ \\
\hline & 4 & $102(95.3)$ & $5(4.7)$ & $0(0)$ \\
\hline & 5 & $93(95.9)$ & $4(4.1)$ & $0(0)$ \\
\hline & 6 & $3(2.0)$ & $110(72.8)$ & $38(25.2)$ \\
\hline & 7 & $7(4.0)$ & $128(72.3)$ & $42(23.7)$ \\
\hline \multirow{5}{*}{ Wede 3} & 3 & $77(97.5)$ & $2(2.5)$ & $0(0)$ \\
\hline & 4 & $97(99.0)$ & $1(1.0)$ & $0(0)$ \\
\hline & 5 & $89(97.8)$ & $2(2.2)$ & $0(0)$ \\
\hline & 6 & $67(53.2)$ & $59(46.8)$ & $0(0)$ \\
\hline & 7 & $76(43.9)$ & $95(54.9)$ & $2(1.2)$ \\
\hline \multirow{4}{*}{ Wede 4} & 3 & $131(98.5)$ & $2(1.5)$ & $0(0)$ \\
\hline & 4 & $125(98.4)$ & $2(1.6)$ & $0(0)$ \\
\hline & 5 & $97(90.7)$ & $10(9.3)$ & $0(0)$ \\
\hline & 6 & $105(85.4)$ & $18(14.6)$ & $0(0)$ \\
\hline \multirow{5}{*}{ Wede 5} & 3 & $87(96.7)$ & $3(3.3)$ & $0(0)$ \\
\hline & 4 & $79(96.3)$ & $3(3.7)$ & $0(0)$ \\
\hline & 5 & $103(95.4)$ & $5(4.6)$ & $0(0)$ \\
\hline & 6 & $99(82.5)$ & $21(17.5)$ & $0(0)$ \\
\hline & 7 & $136(76.8)$ & $35(19.8)$ & $6(3.4)$ \\
\hline
\end{tabular}

translocation, the elimination of both pairs of chromosome a1, and a nondisjunction of an a3 chromosome leading to the appearance of 5 homologous chromosomes. The frequencies of type $\mathrm{S}$ and type II-3 were $77.4 \%$ and $22.6 \%$ respectively. In this callus line and the regenerated plantlets, the structural chromosome changes were found in chromosomes al and a8.

\section{Discussion}

There have been many studies on chromosomal aberrations in cultured plant cells and their regenerants using various plant materials (cf. Singh 1993). Most reports describe only aberrations in chromosome number, such as polyploidy and aneuploidy, and do not mention structural changes induced by deletions, translocations, duplications, inversions, etc. Structural chromosome changes were reported in detail for cultured cells of Crepis capillaris $(2 \mathrm{n}=6)$ and Haplopappus gracilis $(2 n=4)$ with low chromosome number (Sacristan 1971, Sunderland 1977). In both cases, the extent of structural changes increased with multiplication of the ploidy level, and the only regenerants were Crepis plants with normal diploid karyotypes. In contrast, the morphogenetic capacities of few polyploid species, such as Solanum tubelosum (Gill et al. 1980) and Triticum aestivum (Karp and Maddock 1984), were not influenced by aneuploidy, polyploidy or structural chromosome changes. Our previous reports (Ono and Harashima 1983, Ono et al. 1994) using haploid cultured cells $(\mathrm{n}=5)$ from pollen culture of Paeonia lactiflora $(2 \mathrm{n}=10)$ and diploid cultured cells of Scilla scilloides $(2 \mathrm{n}=16)$ also revealed chromosomal aberrations in terms of both chromosome number and structure. Moreover, in Scilla scilloides callus cells, we reported regenerants with aneuploid chro- 

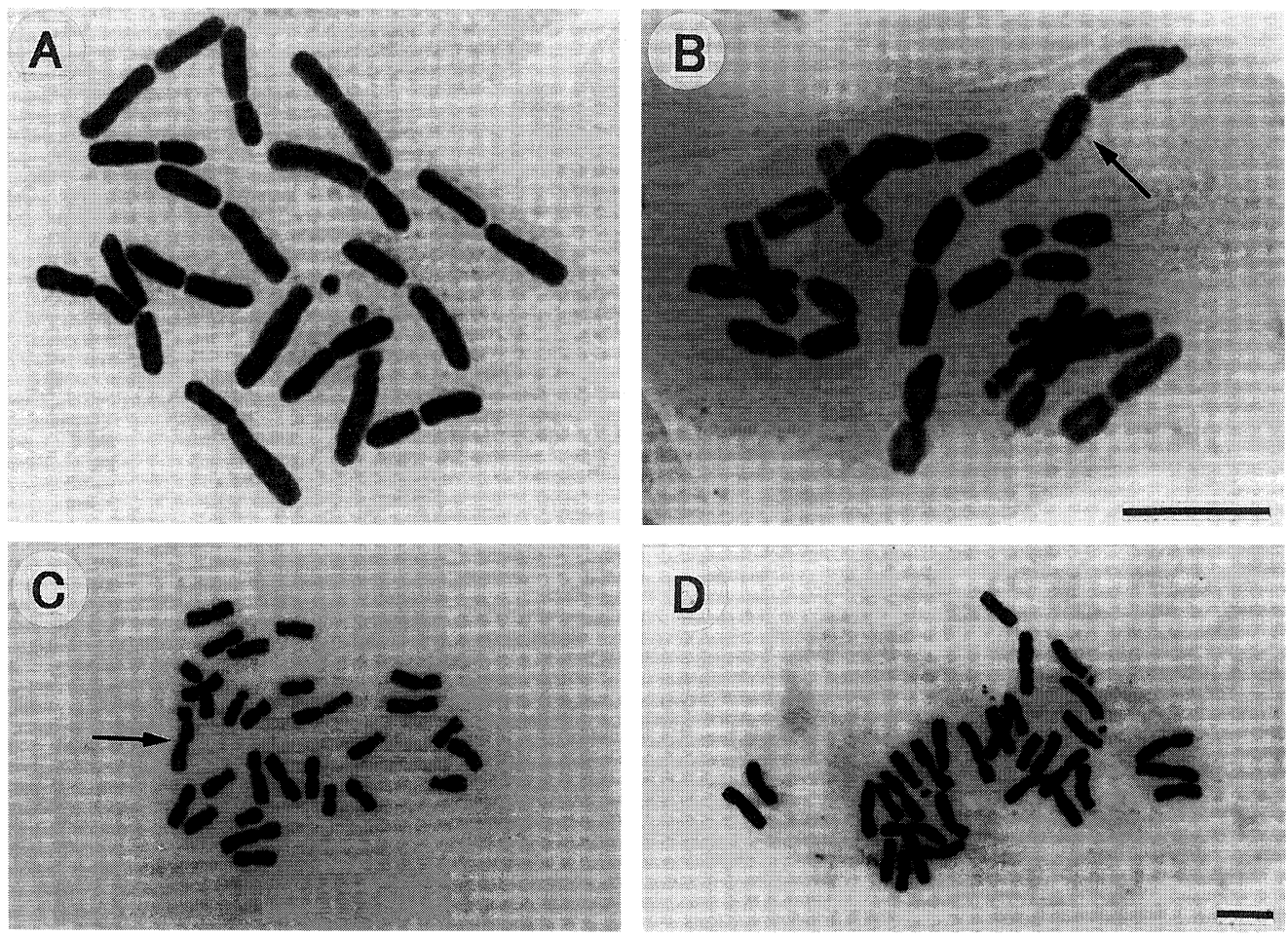

Fig. 2. Metaphase chromosomes of A. fistulosum cv. Kaori. A) a root tip cell of mother plant $(2 \mathrm{n}=16)$. $B, C, D$ ) callus cells (B: $2 n=15, C: 2 n=28, D: 2 n=32$ ), each of arrows indicate a dicentric chromosome. Bars indicate $10 \mu \mathrm{m}$.

Table 4. Karyotypes of Allium fistulosum cv. Kaori

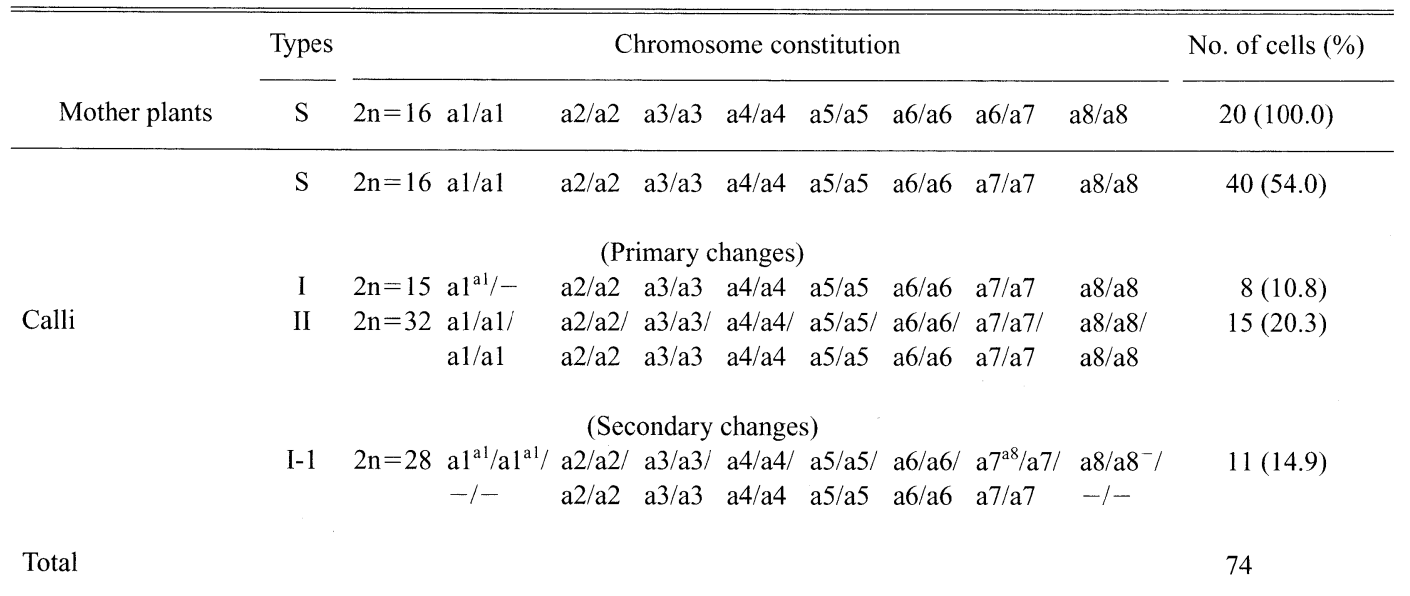

No. of plantlets $(\%)$

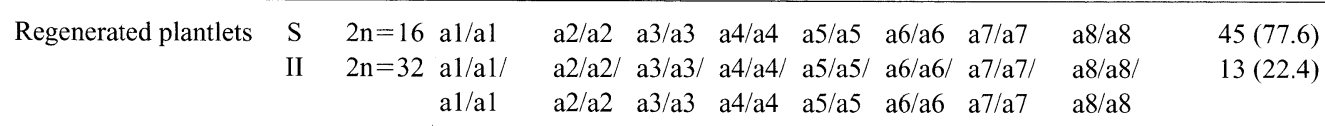

Total

Minus (-) indicate eliminations of chromosomes. Superior symbols indicate deletions $(-)$ and translocations $\left(\mathrm{a}^{*}\right)$ of chromosomes, respectively. 

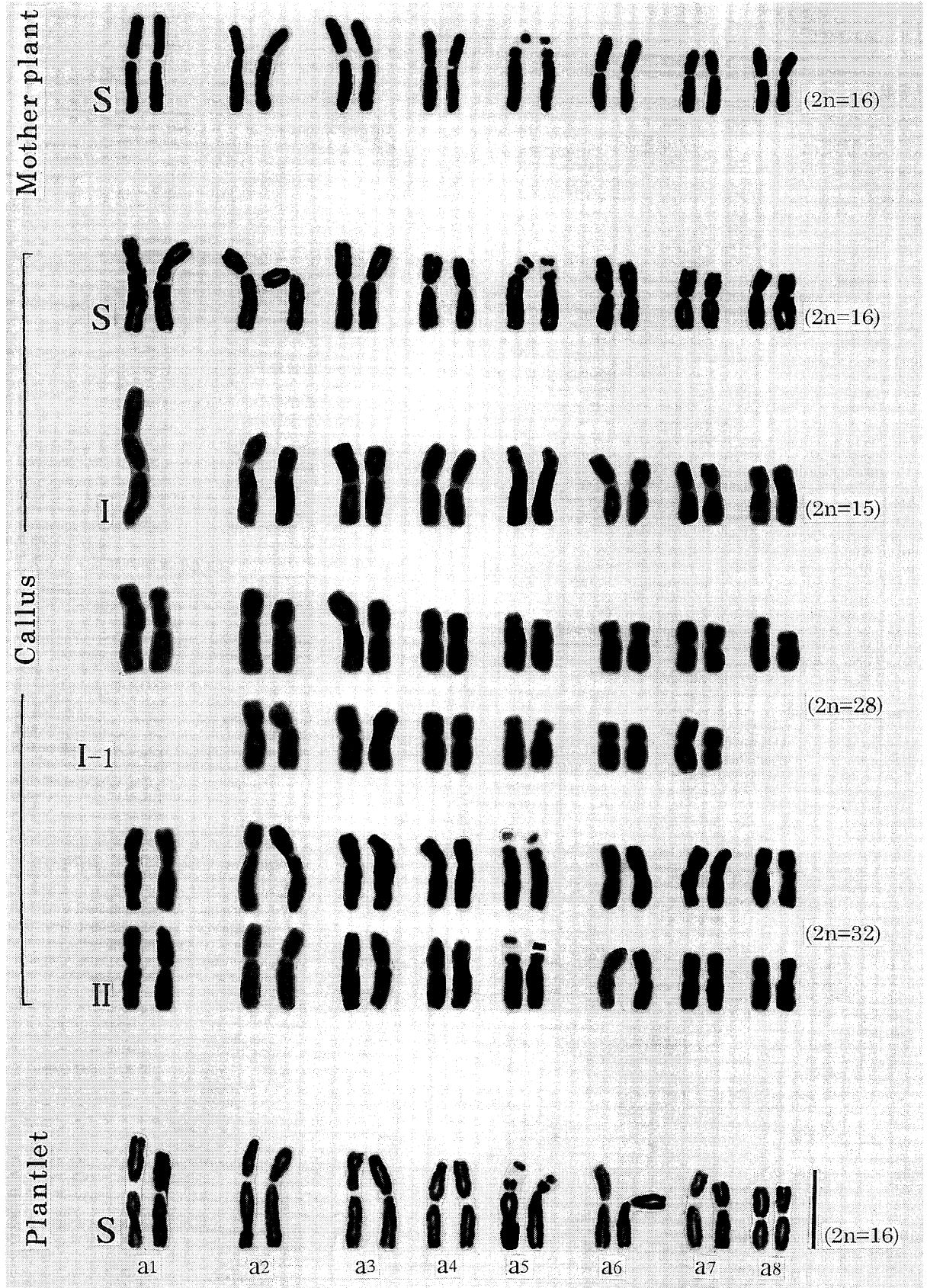

Fig. 3. Karyotypes of mother plant, callus cells and regenerated plantlets of A. fistulosum cv. Kaori. Bar indicates $10 \mu \mathrm{m}$. 
Table 5. Karyotypes of Allium fistulosum cv. resh

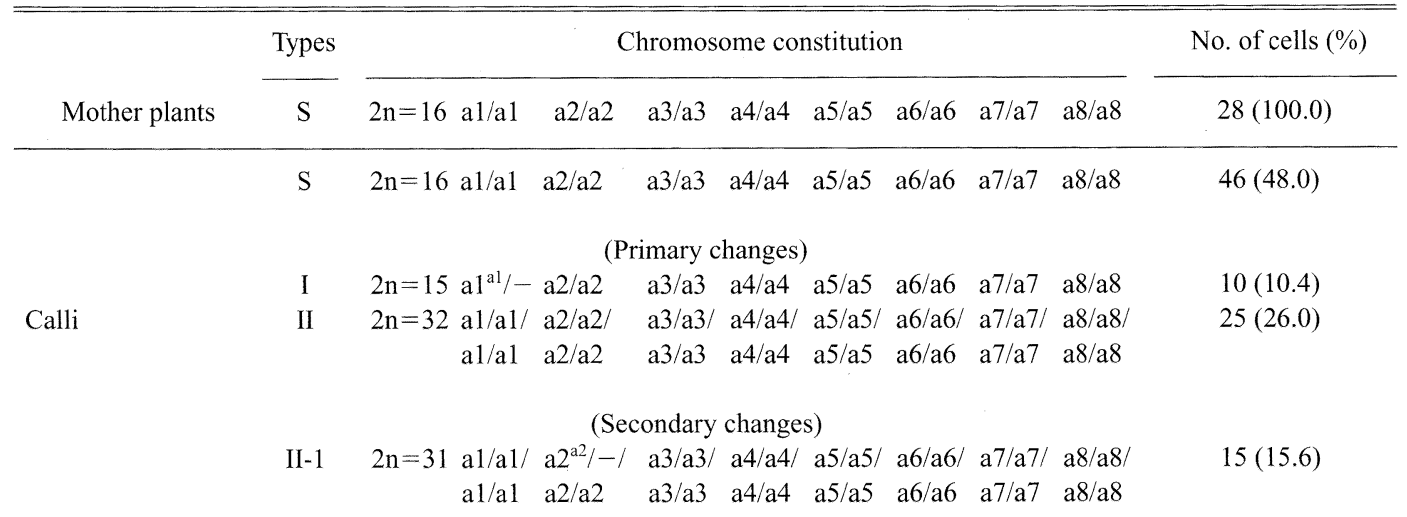

Total

96

No. of plantlets $(\%)$

\begin{tabular}{|c|c|c|c|c|c|c|c|}
\hline \multirow{4}{*}{ Regenerated plantlets } & $\mathrm{S}$ & $2 n=16$ a1/a1 a2/a2 & $\mathrm{a} 3 / \mathrm{a} 3 \quad \mathrm{a} 4 / \mathrm{a} 4$ & a5/a5 a6/a6 & a7/a7 & $\mathrm{a} 8 / \mathrm{a} 8$ & $50(64.1)$ \\
\hline & II & $2 \mathrm{n}=32 \mathrm{a} 1 / \mathrm{a} 1 / \mathrm{a} 2 / \mathrm{a} 2 /$ & a3/a3/ a4/a4/ & a5/a5/ a6/a6/ & a7/a7/ & $\mathrm{a} 8 / \mathrm{a} 8 /$ & $18(23.1)$ \\
\hline & & a1/a1 a2/a2 & a3/a3 a4/a4 & a5/a5 a6/a6 & a7/a7 & a8/a8 & \\
\hline & III & $2 \mathrm{n}=18 \mathrm{a} 1 / \mathrm{a} 1 \quad \mathrm{a} 2 / \mathrm{a} 2$ & $\mathrm{a} 3 / \mathrm{a} 3 \quad \mathrm{a} 4 / \mathrm{a} 4$ & $\begin{array}{l}\text { a5/a5 a6/a6 } \\
\text { a5 }\end{array}$ & $\begin{array}{l}\text { a7/a7 } \\
\text { a7 }\end{array}$ & $\mathrm{a} 8 / \mathrm{a} 8$ & $10(12.8)$ \\
\hline
\end{tabular}

Total

78

Minus (-) indicate eliminations of chromosomes. Superior symbols indicate deletions ( - ) and translocations (a*) of chromosomes, respectively.

mosome numbers and structurally changed chromosomes.

There are very few reports on chromosome aberrations in Allium fistulosum callus cells. Joachimiak et al. $(1993,1995)$ recently reported on chromosome alterations in callus cells of this species, although changes in chromosome structure were not mentioned in detail. In the present study, we found cells with various ploidy levels during subculture of 3 A. fistulosum cultivar callus lines. This result agrees with that of Joachimiak et al. (1993, 1995) described above. We also observed various aneuploid karyotypes with structural chromosome changes that were not found in the mother plants in vivo. In A. fistulosum callus cells, Joachimiak et al. $(1993,1995)$ reported megachromosomes with several centromeres, which were induced by translocations and deletions involving two or more chromosomes. In this study, we also found a dicentric chromosome that was derived from translocation and deletion between two al chromosomes. Thus, the occurrence of dicentric chromosomes may be a common characteristic in in vitro A. fistulosum cultures. In addition, this study found that chromosomes a2, a7 and a8 were the most likely to have structural chromosome alterations.

In regenerated plantlets, numerically and structurally changed karyotypes were also observed, although the rates of diploids and tetraploids were remarkably high. These results indicate that even callus cells derived from a normal diploid and having changed karyotypes were able to maintain the ability to regenerate plants.

Studies on plant regeneration from A. fistulosum callus cells have been reported by several authors (Van der Valk et al. 1992, Song and Peffley 1994, Kim and Soh 1996). These reports concerned plant regeneration occurring through somatic embryogenesis, although detailed descriptions of the process of embryogenesis were not provided. In the present study, we observed plantlet regeneration from callus cells via shoot formation and could not find well-defined somatic embryoge- 

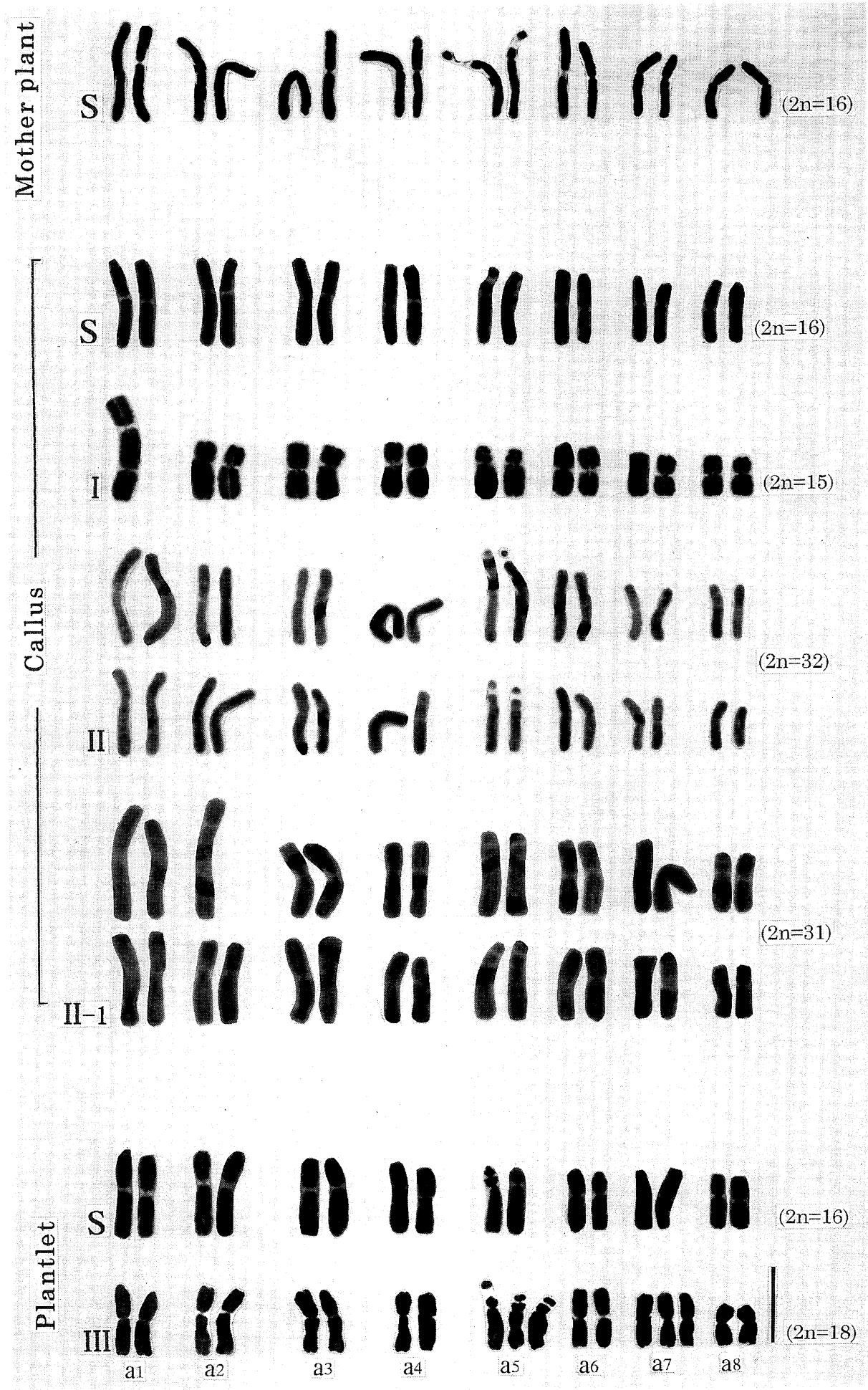

Fig. 4. Karyotypes of mother plant, callus cells and regenerated plantlets of $A$. fistulosum cv. Fresh. Bar indicates $10 \mu \mathrm{m}$. 

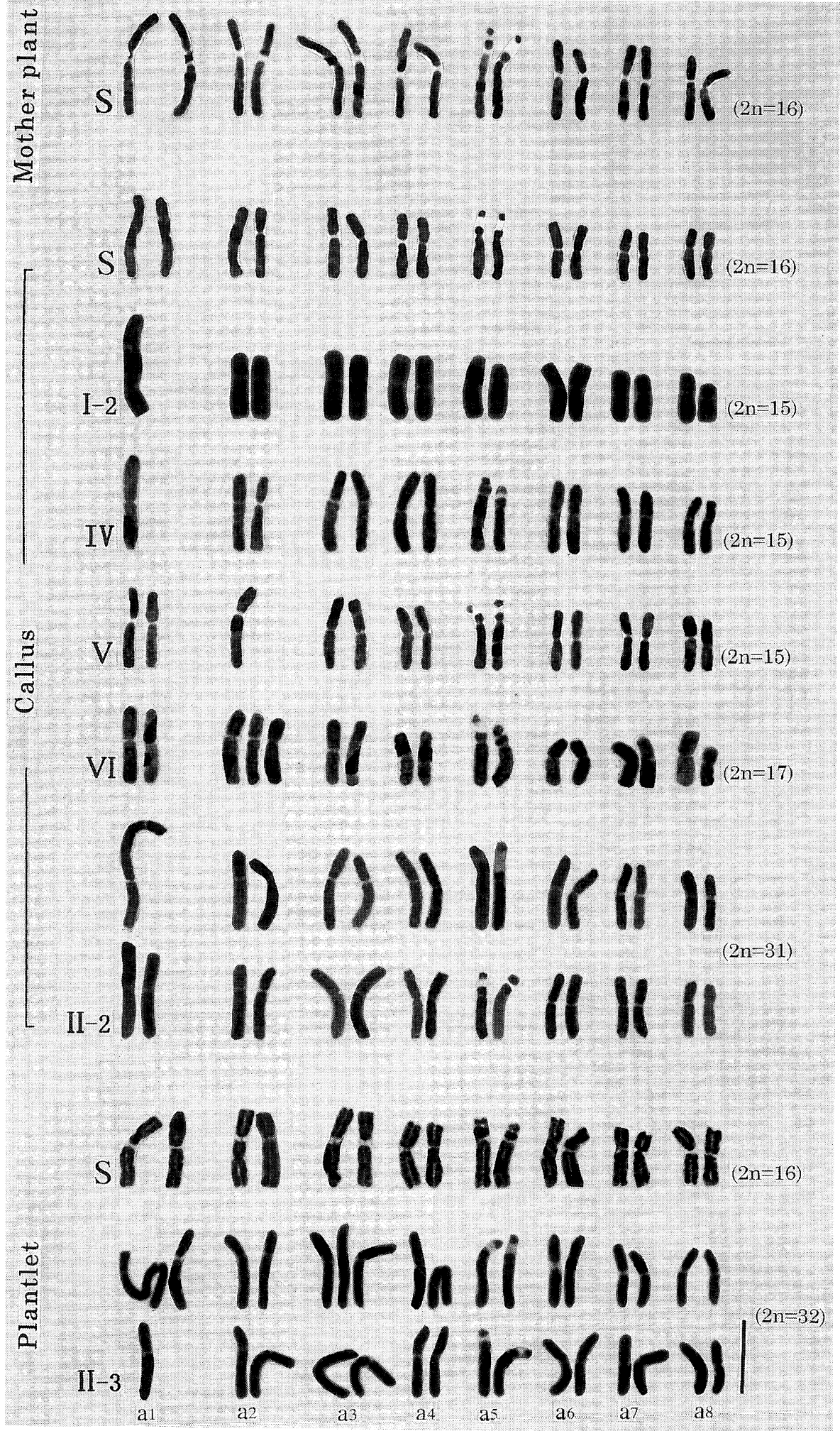

Fig. 5. Karyotypes of mother plant, callus cells and regenerated plantlets of A. fistulosum cv. Wede. Bar indicates $10 \mu \mathrm{m}$. 
Table 6. Karyotypes of Allium fistulosum cv. Wede

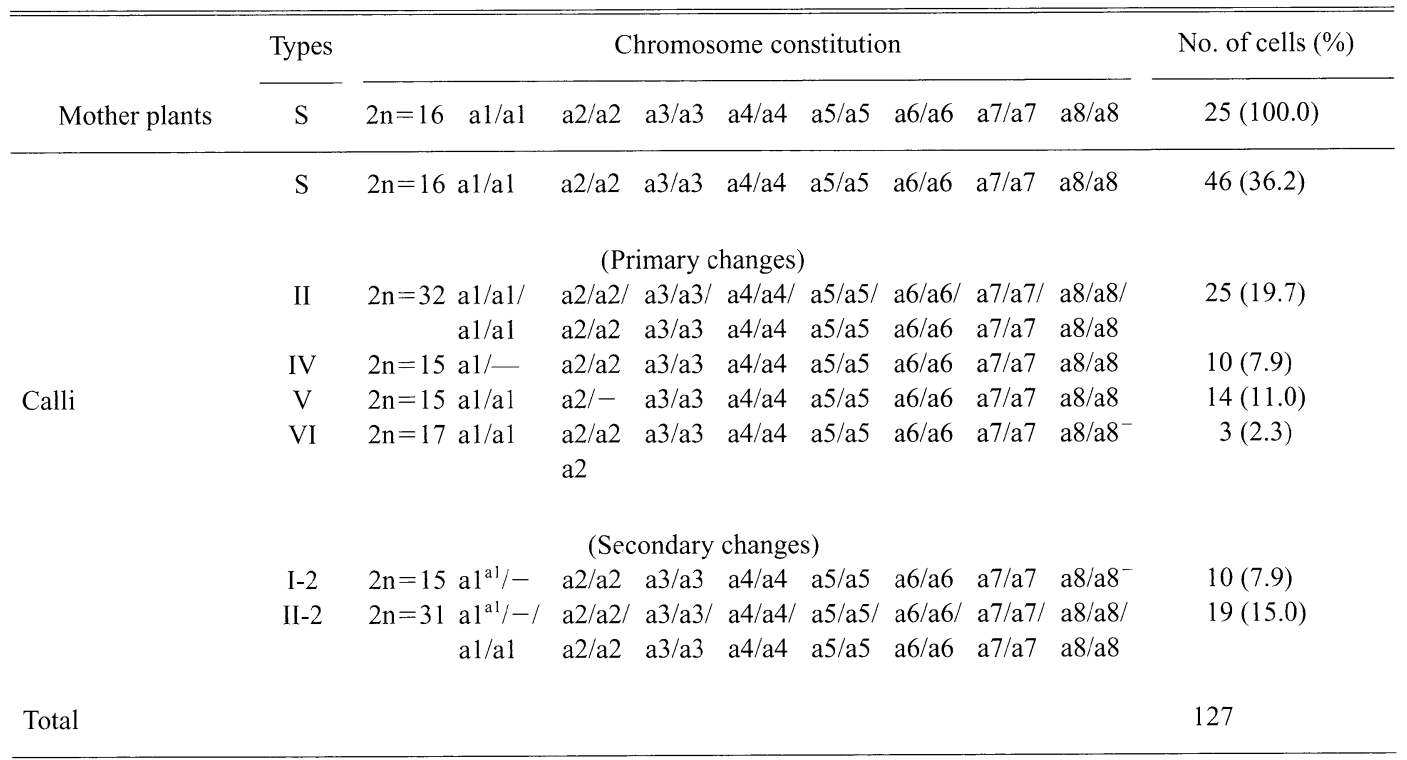

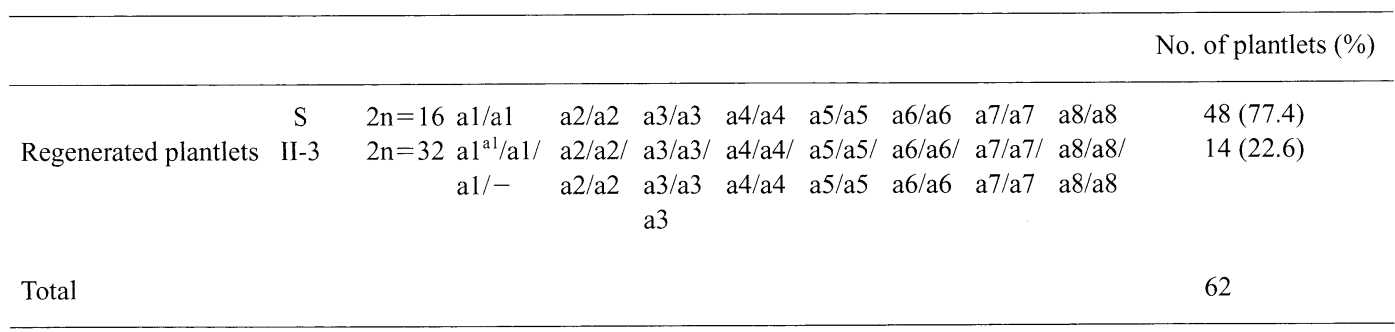

Minus (-) indicate eliminations of chromosomes. Superior symbols indicate deletions $(-)$ and translocations $\left(a^{*}\right)$ of chromosomes, respectively.

nesis. Further study is necessary to elucidate whether morphogenesis from callus cells of this species is due to somatic embryogenesis or shoot formation. We are now histochemically studying the initiation of morphogenesis in A. fistulosum callus cells.

\section{Acknowledgements}

The authors are grateful to Dr. H. Takano for his help and useful advice.

\section{References}

Ayabe, M., Taniguchi, K. and Sumi, S. 1995. Regeneration of whole plants from protoplasts isolated from tissue-cultured shoot primordia of garlic (Allium sativum L.). Plant Cell Rep. 15: 17-21.

Campion, B. and Alloni, C. 1990. Induction of haploid plants in onion (Allium cepa L.) by in vitro culture of unpollinated ovules. Plant Cell Tissue Organ Cult. 20: 1-6.

Constantin, M. J. 1981. Chromosome instability in cell and tissue cultures and regenerated plant. Environ. Exp. Bot. 21: 359-368.

El-Gadi, A. and Elkington, T. T. 1975. Comparison of the Giemsa C-band karyotypes and the relationship of Allium cepa, A. fistulosum and A. galanthum. Chromosoma. 51: 19-23.

El-Gizawy, A. M. and Ford-Lloyd, B. V. 1987. An in vitro method for the conservation and storage of garlic (Allium sativum) germplasm. Plant Cell Tissue Organ Cult. 9: 147-150.

Evans, D. A. and Reed, S. M. 1981. Cytogenetic Techniques. In: Thorpe, T. A. (ed.). Plant Tissue Culture Methods and Application in Agriculture. Academic Press, New York, pp. 213-240. 
Fellner, M. and Havranek, P. 1992. Isolation of Allium pollen protoplasts. Plant Cell Tissue Organ Cult. 29: 275-279.

Gill, B. S., Burnham, C. R., Stringam, G. R., Stout, J. T. and Weinheimer, W. H. 1980. Cytogenetic analysis of chromosomal translocations in the tomato: preferential breakage in heterochromatin. Can. J. Genet. Cytol. 22: 333-341.

Hansen, E. E., Hubstenberger, J. F. and Phillips, G. C. 1995. Regeneration of shoots from cell suspension derived protoplasts of Allium cepa. Plant Cell Rep. 15: 8-11.

Havranek, P. and Novak, F. J. 1973. The bud formation in the callus cultures of Allium sativum L. Z. Pflanzenphysiol. 68: 308-318.

Hong, W. and Debergh, P. 1995. Somatic embryogenesis and plant regeneration in garden leek. Plant Cell Tissue Organ Cult. 43: $21-28$.

Joachimiak, A., Ilnicki, T., Kowalska, A. and Przywara, L. 1995. Chromosome alterations in tissue culture cells of Allium fistulosum. Genetica 96: 191-198.

—, Przywara, L., Ilnicki, T. and Kowalska, A. 1993. Megachromosomes in tissue culture of Allium. Genetica 90: 35-40.

Karp, A. and Maddock, S. E. 1984. Chromosome variation in wheat plants regenerated from cultured immature embryos. Theor. Appl. Genet. 67: 249-255.

Kim, J. W. and Soh, W. Y. 1996. Plant regeneration through somatic embryogenesis from suspension cultures of Allium fistulosum L. Plant sci. 114: 215-220.

Kurita, M. 1952. On the karyotypes of some Allium species from Japan. Mem. Ehime Univ. Sect. II, 1: $179-188$.

Lu, C. C., Currah, L. and Peffley, E. B. 1989. Somatic embryogenesis and plant regeneration is diploid Allium fistulosum $\times$ Allium cepa $\mathrm{F}_{1}$ hybrid onions. Plant Cell Rep. 7: 696-700.

Matsuda, Y. and Adachi, T. 1996. Plant regeneration via embryogenesis in commercial cultivars of Chinese chive (Allium tuberosum Rottl.). Plant sci. 119: 149-156.

Murashige, T. and Skoog, F. 1962. A revised medium for rapid growth and bioassays with tobacco tissue cultures. Physiol. Plant. 15: 473-497.

Nagasawa, A. and Finer, J. J. 1988. Development of morphogenic suspension cultures of garlic (Allium sativum L.). Plant Cell Tissue Organ Cult. 15: 183-187.

Ono, K. and Harashima, S. 1983. Growth characteristics and chromosomal behavior of cell suspension lines established from pollen callus of peony. Jpn. J. Genet. 58: 209-218.

-, Ohgami, H., Takamiya, M., Uchino, A. and Araki, H. 1994. Chromosomal aberrations of cultured cells and regenerated plantlets in the diploid Scilla scilloides (2n=16, AA). Cytologia 59: 261-268.

Orton, T. T. 1985. Genetic instability during embryogenic cloning of celery plant. Plant Cell Tissue Organ Cult. 4: 159-169.

Pandey, R., Chandel, K. P. S. and Rao, S. R. 1992. In vitro propagation of Allium tuberosum Rottl. ex Spreng. by shoot proliferation. Plant Cell Rep. 11: 211-214.

Peffley, E. B. 1992. Micropropagation of Japanese Bunching Onion (Allium fistulosum L.) and its Hybrid (A. fistulosum $\times$ A. сера) Derivatives. In: Bajaj, Y. P. S. (ed.). Biotechnology in Agriculture and Forestry, Vol. 19, Hightech and Micropropagation III. Springer-Verlag, Berlin, pp. 244-260.

Phillips, G. C. and Hubstenberger, J. F. 1987. Plant regeneration in vitro of selected Allium species and interspecific hybrids. Hort. Sci. 22: 124-125.

Rauber, M. and Grunewaldt, J. 1988. In vitro regeneration in Allium species. Plant Cell Rep. 7: 426-429.

Sacristan, M. D. 1971. Karyotypic changes in callus cultures from haploid and diploid plants of Crepis capillaris (L.) Wallr. Chromosoma 33: 272-283.

Seo, B. B. and Kim, H. H. 1988. Regeneration of amphidiploid plants from tissue cultures of Allium wakegi. Plant Cell Rep. 7: 297-300.

Shahin, E. A. and Kaneko, K. 1986. Somatic embryogenesis and plant regeneration from callus cultures of nonbulbing onions. Hort Sci. 21: 294-295.

Shuto, H., Abe, T. and Sasahara, T. 1993. In vitro propagation of plants from root apexderived calli in Chinese chive (Allium tuberosum Rottl.) and garlic (Allium sativum L.). Jpn. J. Breed. 43: 349-354.

Silvertand, B., Jacobsen, E., Mazereeuw, J., Lavrijsen, P. and van Harten, A. 1995. Efficient in vitro regeneration of leek (Allium ampeloprasum L.) via flower stalk segments. Plant Cell Rep. 14: 423-427.

Singh, R. T. 1993. Chromosomal Aberrations in Cell and Tissue Culture Derived Calluses and Their Regenerants. In: Plant Cytogenetics. pp. 285-307. CRC Press, Boca Raton.

Song, P. and Peffley, E. B. 1994. Plant regeneration from suspension cultures of Allium fistulosum and an A. fistulosum $\times$ A. cepa interspecific hybrid. Plant Sci. 98: 63-68.

Sunderland, N. 1977. Nuclear Cytology. In: Street, H. E. (ed.). Plant Tissue and Cell Culture. Blackwell Sci. Publ. Oxford, pp. 161-190.

Van der Valk, P., Scholten, O. E., Verstappen, F., Jansen, R. C. and Dons, J. J. M. 1992. High frequency somatic embryogenesis and plant regeneration from zygotic embryoderived callus cultures of three Allium species. Plant Cell Tissue Organ Cult. 30: 181-191. 
Xue, H. M., Araki, H., Kanazawa, T., Harada, T. and Yakuwa, T. 1997. Callus formation and plantlet regeneration through in vitro culture of immature embryo and seedling in Chinese chive (Allium tuberosum Rotti.). J. Jpn. S. Hort. 66: $353-358$. 